\title{
Academia as a league system
}

\section{Aloys Prinz ${ }^{1}$ (D) Thomas Ehrmann ${ }^{2}$}

Accepted: 30 December 2021 / Published online: 12 January 2022

(c) The Author(s) 2022

\begin{abstract}
In this paper, we explain the stability of top university ranks and discuss attempts to create top national universities. Firstly, it is shown theoretically that in a world with differently-gifted poor and rich students, a three-tier university system may become very stable, with a super league of the best research universities that attract the best students, whether rich or poor. Secondly, it is empirically demonstrated that half of the highest ranked universities enjoy very stable competitive advantages. Thirdly, we examine attempts of China, France and Germany to overcome these disadvantages and to get into this super league. The recent attempt of China to create such super league universities shows the financial and societal costs of these attempts. France demonstrates how the concentration of financial resources on two newly built universities that complement the forces of existing ones-either real or only by labelling - may succeed. Despite the complexly designed and competitive German Excellence Initiative, ongoing since 2004, no German university was among the top 50 in the Shanghai ranking in 2021 (compared to one university in 2004). The mixed results of all these worldwide attempts may reflect the problem that late market entry into the super league may be too costly, given that the classical university business model is in the mature phase of its life cycle.
\end{abstract}

Keywords University ranking - Super league - Three-tier league - Talent allocation · Students $\cdot$ Researchers

JEL Classification A20 - F20 $\cdot$ H52 $\cdot$ I23 $\cdot$ I28 $\cdot$ M21

Aloys Prinz

Aloys.Prinz@wiwi.uni-muenster.de

Thomas Ehrmann

Thomas.Ehrmann@ism.uni-muenster.de

1 Institute of Public Economics, University of Muenster, Wilmergasse 6-8, 48143 Muenster, Germany

2 Thomas Ehrmann, Institute of Strategic Management, University of Muenster, Leonardo-Campus 18, 48149 Muenster, Germany 


\section{Introduction}

What does it take to get into the super league of universities, and what does it take to stay there? Global recruiting of high potentials is the foundation for creating knowledge, innovation and competitive advantages. As Hazelkorn put it, "[a] round the world, rankings consciousness has risen sharply and, arguably inevitably, in response to globalization and the pursuit of new knowledge as the basis of economic growth, and the drive for increased public accountability and transparency" (Hazelkorn 2011, p. 4; see also Hazelkorn 2015, chapter 4, pp. 133 ff.). Companies, universities and other organizations compete hard in this so-called war for talents. But the global competition between the firms that compete for these talents seems to be very different from the global university competition. When we look at the top 50 and top 20 universities in the Shanghai Ranking there is a high stability of both ranking intervals, increasing with the rank positions (MacLeod and Urquiola 2021).

Most of the above-mentioned talents are educated at universities. However, only a few studies analyze the global university system (e.g., Marginson 2006; Grewal et al. 2008; Kehm and Stensacker 2009; Altbach and Salmi 2011; Hazelkorn 2015; Moed 2017). In particular, the competition of universities in the global system of university has not yet been adequately studied. This paper contributes to the explanation of this competition by firstly proposing a simple theoretical model of it. Then, secondly, it is empirically demonstrated that the ranking positions in the top 20 and top 50 universities in the Shanghai University Rankings of 2004-2021 are very stable. Thirdly, recent attempts to jump into the top ranking positions by China, Germany and France are critically discussed. Although not impossible, it is very costly to establish a super league university as there are only a small number of crucial tools that can be adjusted: financial endowments, high-quality researchers and highly-able students. Moreover, the regulatory framework, as well as university governance (Blackman and Kennedy 2009), may play a role. This raises the question as to whether it is reasonable at all to try to get a super league university.

Besides skills, universities offer 'positional goods' to students that provide access to social prestige and income-earning (Basu 1989). Research universities compete for status as producers of positional goods. They compete so strongly for students that it is even asked whether there is too much competition (Mause 2009). The global market for universities is hierarchically structured in the sense that some institutions require higher standards from researchers and students than others, although all types of institutions recruit from the same world student population. The higher the university rank is, the more valuable the positional good for students.

Worldwide it seems to be very attractive for students to attend the leading institutions. In global competition of a worldwide positional market elite, US/ UK universities are on top of the hierarchy; they are followed on the next lower levels by a market segment led by UK and Australian universities. A look at the global university rankings over the last 15 years shows that the market segments 
appear to be very stable amongst the top-tier institutions, with only small changes from the rank number 50 onwards. In addition, there is evidence of an increase in the stratification of the student population, with leading institutions recruiting an ever-increasing number of the brightest students from all over the world, while less bright students attend local universities with a lower reputation (see Cook and Frank 1993). As it seems, students assume that the future benefits of choosing a high-reputation university outweighs the respective costs.

From the perspective of continental Europe, the status quo is bleak. In the 2021 Shanghai University Ranking, only five non-US institutions are amongst the top 20, three from the UK and one from France and Switzerland, respectively. None of the 88 public universities in Germany that are authorized to award doctoral degrees has ever appeared among the leading universities worldwide in commonly consulted international rankings. This underperformance has a negative impact on both the education of high potentials and their inclination to the German labor market. To dramatically improve the performance of the university system, in 2004 the federal ministry for higher education and research proposed that the government should simply select and support six universities to be Germany's top institutions of higher learning. This ongoing process started then the so-called "Excellence Initiative". It financed in the first round with 1.9 billion euros, a big sum by German standards.

The number of top-tier universities in the United Kingdom and Switzerland seems to be compatible with the (relative) size of their economies since UK's GDP is 4.00 times as large as that of Switzerland (GDP data are from World Bank 2019). The German economy is larger than the UK's and 5.67 times that of Switzerland. In comparison to its GDP, Germany should have about six universities in the same rank as Switzerland and the UK. The GDP of France is 3.86 times as large as the Swiss one and could have an according number of top universities. Moreover, China's GDP is 19.29 times as large as that of Switzerland; it could have about 20 universities in the highest rank if the distribution of equally-ranked universities were proportional to the countries' GDPs. For comparison, The US GDP is 29.05 times as large as the Swiss GDP and, therefore could have 29 universities in the same rank as Switzerland. According to the Shanghai University Rankings, the USA, UK and Switzerland have considerably more highly-ranked universities in comparison to their GDPs. China and Germany, in contrast, have less highly-ranked universities than expected by their GDPs. The ranking criteria of the Shanghai University Ranking are shown in Table 1. Note that research output, in particular publications, play a central role for the ranking position.

China invested heavily in higher education. In 2016, Chinese researchers published globally the largest number of scientific and technical papers (from 86,621 in 2003 to 426,165 in 2016) with the USA as runner-up (from 321,766 in 2003 to 408,985 in 2016) (World Bank 2017; most recent values). Between 2003 and 2016, the number of scientific and technical papers increased in China by $13.58 \%$ p.a., in the USA by $1.92 \%$ p.a. (Germany: $3.04 \%$ p.a.). Although China is only on rank seven concerning this growth rate, it surpassed the US in the absolute number of such articles. This strong increase is an indication of the Chinese effort to get into the top-ranked positions of the global university ranking. As of today, China has five universities among the Top 100 universities (Shanghai University Ranking, 2021, 
Table 1 Ranking criteria and their weights in the Shanghai University Ranking

\begin{tabular}{lll}
\hline Criteria & Indicators & Weighting \\
\hline Educational quality & Alumni winning Fields Medals and Nobel Prizes & $10 \%$ \\
Faculty quality & Staff winning Fields Medals and Nobel Prizes & $20 \%$ \\
Faculty quality & Highly cited researchers & $20 \%$ \\
Research output & Papers in Science/Nature; academic papers in Science & $20 \%$ (Science/ \\
& Citation Index-Expanded and Social Science Citation & Nature or equiva- \\
& Index & lent), 20\% \\
Performance & Academic performance per-capita & $10 \%$ \\
Total & & $100 \%$ \\
\hline
\end{tabular}

Source: https://www.shanghairanking.com/methodology/arwu/2020 [Accessed July 07, 2021]

rank 29, 49, 58, 63 and 100), one university more than Germany (Shanghai University Ranking 2021, rank 51, 54, 57 and 87). Chinese universities improved their ranks since the former 2019 ranking, with one university now on position 29 . However, it is an open question whether and how many of these high-quality universities these countries could support in the long-term.

Accordingly, a pressing question for both politicians and researchers alike is the degree of stability of the top ranks in university rankings. There seem to exist different "leagues " of universities. The idea of a league of universities was formulated by the heads of four of Britain's top-rated universities, published in an article in The Observer newspaper (Williams 1997). As in the European discussion about a "super league" in soccer, the university heads were moving in similar direction by demanding the creation of a "super league" of universities. They argued that a new league of about 12 institutions should be given enough money to bid for the world's best researchers and to buy top-quality equipment.

In this paper, the hierarchical structure of universities in "leagues" is taken as a starting point for the analysis. The focus is on the allocation of researchers and students to universities in the respective "leagues". Since the allocation of students to different universities is paramount for their success, this allocation process is analyzed first. Then we develop a stylized model to analyze how universities retain their rank position in global research and teaching league-hierarchy. Afterwards, we empirically demonstrate with the Shanghai University Rankings of 2004-2021 that more than half of the highest ranked universities are in a very stable position. These universities form, therefore, a super league. We then analyze attempts to get into this super league. While it is not impossible, it requires huge investments in one or two national universities. Countries like Germany with its Excellence Initiative or China try to upgrade their universities and to improve their respective ranking positions. The chances of success of these efforts (MacLeod and Urquiola 2021) will be analyzed with our model.

Universities as multi-product institutions are supplying different sorts of output. They offer teaching, research and something that can be called public services (Cohn and Cooper 2004). Teaching is about transferring knowledge to students (Demange et al. 2020). The creation of knowledge is the task of research. The efforts of research are complements to teaching, at least in postgraduate courses (Qamar uz 
Zaman 2004; Poole 2018; Bezès 2021). Public services, as the third output, include e.g. the awarding of diplomas that have a legally recognized value for the civil service in some countries.

Universities compete for students because universities adopt a customer-input technology, i.e. students are at once inputs (producers) and customers of the educational process (Rothschild and White 1995). Students are very important inputs that are required to produce education but they also provide funds to universities both by paying tuition fees and by allowing universities to receive government grants. Empirical studies verify that students use university rankings as an aid for their personal decision on the place of study (see the referenced studies in Hazelkorn 2015, chapter 4). Put differently, potential students and their parents are applying ranking positions as a proxy indicator for universities' reputation. Moreover, there is a strong positive correlation between students' quality and the ranking position of universities in Europe (Hazelkorn 2015, p. 155, quoting Roberts and Thompson 2007). For the ranking of universities, criteria for the quality of the faculty and research output are applied. For instance, the Shanghai ranking uses the criteria shown in Table 1. Although national rankings may be less demanding, educational quality, faculty quality, as well as research output, are also — among others-usually applied.

In our stylized model, universities are not simply profit maximizers but they have two objectives: earning income and generating (research and teaching) quality. Almost the same holds true for university professors (Becker 1975, 1979). This has a direct impact on the quantity of government (and private) grants the respective universities can earn. As will be shown, the mentioned objectives are interwoven. To achieve their objectives, universities employ either highly or moderately gifted researchers and they demand either high or low tuition fees from students. Because students are at once inputs and customers of the educational process, their quality is very important for the performance of universities. Students may be highly or moderately gifted and, in addition, they are either rich or poor. Their objective is getting a (valuable) signal for their own academic quality via the universities they studied. One problem of students' allocation to universities is the fact that highly gifted students may be rich or poor; for simplicity of the analysis, it is assumed that all moderately gifted students are rich (see Basu 1989).

The interaction between students and universities usually proceeds as follows: universities set admission standards and tuition fees, and those students who qualify for admission choose whether to accept the offer or not. A student who achieves the admission standard at more than one university chooses which university to attend. To make this choice, students take account of the tuition fees. They also evaluate the quality signal of the university for their (future) labor market income. The university they attended is a signal for the quality of the university and, hence, of the respective students. To analyze these questions more formally, we assume that universities act as organizations that offer a certain quality level of research, in order to 'sell' a respective signal to students.

Universities may generate income via research grants which depend on the quality of researchers. Researchers prefer to teach high-quality students. For instance, Becker and Kennedy (2005) provide survey evidence from eminent economists that their teaching enhances their research. Moreover, they argue that teaching and research 
may even be complements because of joint production (Becker and Kennedy 2005, p. 173; Bezès 2021). The outcome of teaching depends on the combined quality of students and their learning capabilities. As is seems, peer effects among students-i.e., clever students are profiting from other clever students at the same university - can have some positive effects on academic achievement (Zimmerman 2003; Winston and Zimmerman 2004). Hence, a combination of high-quality researchers and high-quality students may generate research quality that in turn may earn research grants later on. For instance, the presence of foreign graduate students had significant positive effects on future patent applications and patents awarded to universities and other institutions (Chellaraj et al. 2008). The importance of excellent education in "research-rich" universities was also recently recognized by the League of European Research Universities (LERU 2017). In turn, high-quality students are looking for prominent, high-quality researchers. The reason is that the job market signal students 'buy' is of higher value when it is more difficult to get it and the better the university's reputation is (Dillon and Smith 2019).

A final argument for the matching of student and researcher quality in universities can be found in the so-called Shanghai University Rankings (Shanghai University Rankings 2004, 2009, 2014, 2019, 2021). A university's total number of alumni who won a Nobel prize or a Fields medal (mathematics) gets a ten percent weight in the calculation of a university's rank (see Table 1). Alumni are persons who obtained a bachelor's, master's or doctoral degree at the respective university, whereby also the date of receiving the degree is recognized, with the highest weight for the most recently obtained degrees. Obviously, having very successful alumni indicates highest-quality research that provides a valuable signal to prospective highly-gifted students. In addition, the latter provide a pool of potentially high-quality researchers. In a sense, highquality students bring about high-quality research that brings about high-quality teaching for high-quality students that brings about high-quality research and so on.

In summary, it can be said that the joint "production" of research and teaching, as well as positive externalities through peer effects in equally gifted students, are among the reasons why student performance and researcher quality are related to each other.

The paper proceeds as follows: A review of the relevant theoretical and empirical literature is given in Sect. 2. In Sect. 3, we present a highly stylized league model of academia. The allocation of (highly and moderately gifted) students to different universities is analyzed in Sect. 3.1. Subsequently, we analyze with our stylized model how universities gain their rank position in the global research and teaching hierarchy in Sect. 3.2. In Sect. 4, we provide some empirical evidence on the stability of universities' rankings. The German Excellence Initiative and Chinas efforts to upgrade their universities is analyzed in Sect. 5, that deals with successful entry into the super league. Section 6 concludes.

\section{Literature review}

In this review, we restrict ourselves to theoretical and empirical papers that investigate the allocation of students with heterogeneous abilities to universities. Since this allocation plays a crucial role in a "league" system of universities, the existing 
literature on this process is of high relevance. Moreover, our paper is a contribution to this literature.

An early paper on school competition for students who are looking for schools with high reputation is Basu (1989). School reputation will bring about higher wages after students' graduation. There are four types of students, high-quality and moderate-quality rich and poor students, respectively. When schools are allowed to ask different tuition fees, high-quality rich and poor students may under certain conditions concentrate on high-quality schools whereas moderate-quality students will then attend schools with moderate quality. In our paper, Basu's approach is applied and complemented by universities' competition for researchers of different qualities.

In a path-breaking paper, Rothschild and White (1995) model universities as competitors for students because universities adopt a technology in which customers are inputs. This means that students are at once inputs and customers of the educational process. Although students are crucial inputs to produce education, they also provide funds to universities by both paying tuition fees and allowing universities to get research grants from the government. The paper of Rothschild and White (1995) has laid the foundation for all subsequent papers on university competition. The main result of their paper is that competitive universities are capable of charging very low tuition fees that efficiently allocate resources. In particular, they show that universities internalize the apparent externality that is created by the influence of students on the output of other students. In this paper, we build on the insights of Rothschild and White (1995); in addition, we model explicitly the effect of students' quality on the quality of researchers which is absent in Rothschild and White (1995) paper. We assume universities as organizations that are screening for high-quality students by offering themselves a certain quality level of research, to provide a reputation (status) signal for students. In this way, universities may generate income from research grants, which depend on the quality of researchers and students alike.

In a recent paper, MacLeod and Urquiola (2015) analyze stratification as a distinctive feature of competitive education markets. They point out that higher education institutions have an incentive to base their reputation on the identity of their students. The reason is that students may apply the school they studied as a signal for ability. Because of the positive externality created by highly able students for their peers, equally gifted students concentrate at the respective schools. The consequence is stratification in higher education. Moreover, this also implies that top schools remain small. Reputational concerns may have furthermore unintended consequences with respect to students' admission effort. To gain admission to selective schools, students invest in the preparation for admission tests, while they reduce their post-admission study effort.

MacLeod and Urquiola (2015) assume that all colleges charge the same tuition fees, which they normalize to zero. In this paper, it is supposed that there exist different tuition fees according to the type of student (rich or poor, highly ore moderately gifted). Moreover, universities do not only compete for students but also for researchers and research grants.

Hoxby (2009) summarizes the empirical evidence about the changing selectivity of American colleges. In line with the theoretical results of MacLeod and Urquiola (2015) she states that the top 10 percent of colleges are significantly 
more selective in 2009 than they were in 1962. While the number of places there has only grown at approximately the same rate as the number of highly qualified students, growth was much higher at schools of lower quality. Overall the selectivity decreased at 50 percent of colleges at least in this time interval. The explanation that fits the high selectivity data, e.g. measured in higher SAT-Test results at the top 10 percent colleges, follows the change in elasticities of college preferences with respect to the proximity among students who are very well qualified for college. While these used to attend a local college regardless of their abilities and its characteristics, their choices are now based on a college's quality, resources and student body. This re-sorting of high-quality students away from local colleges to top tier colleges caused selectivity to rise in this small number of colleges. On the other hand it has the consequence of decreasing selectivity in other colleges.

In addition, the congruence between college quality and student ability appears in students' college degree completion and earnings (Dillon and Smith 2019). This provides empirical evidence for assortative matching of the institutions and their students. Nevertheless, the match is not perfect. According to Dillon and Smith (2017), there is undermatching of high ability students at low quality colleges and overmatching lower ability students at high quality colleges. In particular, better informed students seem to cause overmatching. Moreover, high-ability students from low income families are underrepresented in high quality colleges (Hoxby and Avery 2013). To change this, information policies and aid guarantees for these students are suggested (Hoxby and Turner 2015; Dynarski et al. 2018).

De Fraja and Iossa (2002) focus on a university's allocation of its resources to research and teaching, as well as on the choice of admission standards. The novel aspect they introduce is students' mobility costs. When mobility costs are high, symmetric equilibria are feasible. Asymmetric equilibria, that allow, for instance, elite universities, exist for moderate mobility costs. In this paper, mobility costs are not considered. The allocation of students to universities depends, among others, on the universities' prestige as a signal for their graduates' ability.

This paper is also related to Romero and Del Rey (2004) who investigate the strategic role of prices/tuition fees and exams/admission standards for public and private universities, competing for students. We do not explicitly model borrowing constraints as in the mentioned paper because we assume that profitable private universities do not have a binding borrowing constraint even when some tuition fees do not cover the respective costs. In contrast to Romero and Del Rey (2004), the focus in this paper is on the endogenous determination of a hierarchical global system of universities. We also find in contrast to Romero and Del Rey (2004) that private universities without borrowing constraints will exhibit higher quality of research and teaching than borrowing-constrained (e.g., public) universities.

In the model of Oliveira (2006), a private and a public university compete for heterogenous students with tuition fees and admission standards. Students will earn higher wages after graduation if they studied at the higher-quality university. In addition, it is assumed that the private university behaves profit-maximizing, while the public university is a welfare maximizer. The main result is that in equilibrium the universities will always set different standards, with the private or the 
public university setting the higher standard. In this paper, with different tuition fees and admission standards, a three-tier league equilibrium emerges when universities compete concerning the quality of both students and researchers.

Grazzini et al. (2011) investigate how students are allocated to public universities that compete for resources. Although different research and teaching equilibria, as well as students' ability-related equilibria may emerge, the most efficient equilibrium consists in an elite university with highly-gifted students only. Students with lower abilities attend the remaining universities that provide nevertheless the same teaching quality. In our paper, private universities compete for students and research grants with the result of a three-tier university system.

In the following section, a league model of academia is developed in order to enhance previous models by including researchers' quality in the competition game between universities for students.

\section{A league model of academia}

\subsection{Allocation of students and researchers to universities}

The main topic of the following model is to determine the allocation of highly and moderately gifted students to institutions of higher education (in the following: universities). Thereby the quality of students is either high or moderate and the students are either rich or poor (see Basu 1989, for these assumptions). As indicated by Basu (1989), it is sufficient to differentiate between rich and poor high-quality students on one hand and moderate-quality rich students on the other hand. The model presented here is an extension of the Basu model by incorporating researchers.

Universities are assumed to have two objectives:

(a) generating income and

(b) generating (research and teaching) quality.

To achieve these objectives, universities employ either highly or moderately gifted researchers and they demand either high or low tuition fees from students.

Students are interested in getting a signal for their own academic quality via the universities they studied. This means that the quality of graduates is not immediately observable. The university of study is accepted by potential employers as a signal for ability and skills, and rewarded by a premium on wages. As stated above, students may be highly or moderately gifted and they are either rich or poor. Rich means that they are able to pay the regular tuition fees, whereas poor implies that they cannot afford these fees (Basu 1989).

Universities provide higher education for students by choosing their quality level of research, $R$, in order to 'sell' a signal $S(R)$ for skills and reputation to students. The latter are interested in $S(R)$. Moreover, universities may generate income from research grants, provided by the government. These grants depend on the quality of researchers that may be high, $h$, or moderate, $m$ : $0<R_{m}<R_{h}$. 
Table 2 Tuition fees of U.S. colleges and universities (in constant 2018-2019 USD)

\begin{tabular}{llll}
\hline Year & Public institutions & Private institutions & All institutions \\
\hline $2000-2001$ & 10,973 & 30,916 & 16,175 \\
$2010-2011$ & 15,540 & 36,515 & 21,165 \\
$2018-2019$ & 18,383 & 44,306 & 24,623 \\
Increase \% p.a & 2.75 & 1.91 & 2.24 \\
\hline
\end{tabular}

Source: US Department of Education (2021) and own calculations

Researchers obtain a constant wage per unit of quality, $w$. That means $w \cdot R_{h}>w \cdot R_{m}$. Moreover, since researchers are also teachers, they are interested in the quality of students. For instance, teaching good students may enhance research (Becker and Kennedy 2005). In particular, when they have a choice, they prefer to teach high-quality students: $R\left(q_{i}\right)$, where $q_{i}$ means the average quality of students at university $i$. One might argue that researchers are only interested in the quality of $\mathrm{PhD}$ students. This is in contrast to the criteria that top universities apply to select their students even at the undergraduate level (Hoxby 2009). One of the reasons is that students may provide positive externalities to each other, so called peer effects. Goods students may become even better when studying together with other highly gifted students (Rothschild and White 1995; Zimmerman 2003; Winston and Zimmerman 2004). Moreover, good undergradutes provide an excellent pool of potential master and PhD students. This may matter for researchers even if they do not teach at the undergraduate level. Highly gifted students are also a signal the university uses to attract potential researchers.

The university maximizes profit by employing talented high-level or moderatelevel researchers and by demanding tuition fees from prospective students, $F$. Moreover, a university may be endowed with foundation assets, $A_{i} \geq 0$. Universities are allowed to demand different fees from different types of students. These fees may be high, $h$, for rich students and low, $l$, for poor students: $0 \leq F_{l}<F_{h}$. Moreover, universities are interested in receiving research grants, $G$. The higher the quality of researchers, the higher the grants: $\frac{d G(R)}{d R}>0$. Hence: $G\left(R_{h}\right)>G\left(R_{m}\right)$. Universities offer a profit maximizing packages $\left(R_{i}, F_{j}\right)$ to prospective students.

Tuition fees are an important source of financial means for universities and colleges in the U.S. Table 2 shows the development of these fees for public, as well as private colleges and universities.

In particular, the fees for studying at a private (non-profit or profit) institution are more than double the fees at public institutions. In very selective elite universities, tuition fees are even higher. Table 3 presents the tuition fees of five top U.S. universities.

The tuition fees in top-ranked UK universities are somewhat lower for international students, but nevertheless high (University of Cambridge: 28,130-73,460 USD for undergraduates and 36,980-42,190 for graduates; however, they are considerablely lower for UK und EU students due to government regulations, Laura 2021). All prestigious institutions offer scholarships and followships for students, 
Table 3 Tuition fees in top-ranked U.S. universities 2020/21, in USD per year

\begin{tabular}{llc}
\hline University (rank in Shanghai 2021) & Undergraduate studies & $\begin{array}{c}\text { Postgradu- } \\
\text { ate studies }\end{array}$ \\
\hline Harvard University (\# 1) & 49,653 & 48,008 \\
Stanford University (\# 2) & 55,473 & 54,315 \\
Massachusetts Institute of Technology (\# 4) & 55,450 & 53,450 \\
California Institute of Technology (\# 8) & 54,570 & 52,506 \\
University of Chicago (\# 10) & 57,642 & 49,734 \\
\hline
\end{tabular}

Source: Laura (2021)

as well as financial aid. For instance, at the Massachusetts Institute of Technology, about $89 \%$ of the undergraduates get some financial aid (Laura 2021).

The students (as well as researchers) know their level of ability, their quality. Students provide levels of cleverness, $C$ (Basu 1989), that can be either high, $h$, or moderate, $m$. Students buy the signal $S(R)$ to get respective premium salaries in the job market. The total numbers of clever rich $(C R)$, clever poor $(C P)$ and moderately-gifted rich students $(M R)$ are denoted as follows: $\bar{n}_{C R}, \bar{n}_{C P}, \bar{n}_{M R}$.

The structure of the just described screening game is as follows. Universities provide a contract by offering a combination of research level and tuition fee, $\left(R_{i}, F_{j}\right)$, to screen for students whose ability level they cannot observe. However, it is assumed that universities know whether an applying student is poor. The intention of the offered contract is to induce students to select themselves to those universities that are adequate to their ability level. It is noteworthy to emphasize that students face not only monetary costs, i.e. tuition fees $F$, but also non-monetary cost in form of effort. For instance, to be a moderately-gifted student at a top-level university requires a substantially higher level of effort in order to succeed, in comparison to highly-gifted peers. Hence, the effort costs of students depend on their ability level.

The above described screening game is solved by backward induction to find the subgame perfect equilibrium. Several additional assumptions are required to solve the game.

Students are assumed to have the following preferences:

(1) A $C R$ student prefers a $\left(R_{h}, F_{l}\right)$ university over a $\left(R_{h}, F_{h}\right)$ university and will never choose a university with moderate researchers.

(2) A $C P$ student prefers a $\left(R_{h}, F_{l}\right)$ university over a $\left(R_{m}, F_{l}\right)$ university and cannot afford a university with high tuition fees.

(3) A $M R$ student prefers a $\left(R_{h}, F_{h}\right)$ university over a $\left(R_{m}, F_{h}\right)$ university and will not get offers with low tuition fees.

As shown empirically for the U.S. by Hoxby and Avery (2013), as well as Dillon and Smith (2017), the assortative matching of students to colleges according to student ability and college quality is less than perfect, in particular for lowincome students. The above assumptions abstract from this imperfection. 
Furthermore, for the total number of student types it is assumed: $\bar{n}_{M R} \geq \bar{n}_{C P} \geq \bar{n}_{C R}>0$. This means that the total number of moderately gifted students is larger than or equal to the number of highly gifted, but poor students, which in turn is larger than or equal to the number of highly gifted, but rich students. The latter inequality is motivated by the fact (i.e., a log-normal income distribution) that rich gifted students and their parents are less frequent than gifted poor ones.

For universities, the following capacity constraints are given (Basu 1989, p. 663, Eq. 13 ), with $\bar{n}_{i}$ as university $i$ 's capacity:

$$
\begin{gathered}
0<\bar{n}_{C P}, \bar{n}_{C R}<\bar{n}_{i}, \\
\bar{n}_{M R}>\bar{n}_{i}
\end{gathered}
$$

In addition:

$$
\bar{n}_{C P}+\bar{n}_{C R} \geq \bar{n}_{i}
$$

These constraints say that a university's capacity is larger than the number of either highly-gifted poor students or highly-gifted rich students, but the total number of highly-gifted students is larger than a university's capacity. Moreover, the number of moderately-gifted rich students is also higher than a university's capacity.

The average quality of students is defined as follows, whereby it is assumed that only $C R$ and $C P$ students contribute to quality (Basu 1989):

$$
\begin{gathered}
q_{1}:=\frac{\bar{n}_{C R}+\hat{n}_{C P}}{\bar{n}_{C R}+\hat{n}_{C P}}=1 ; 0<\widehat{n}_{C P}<\bar{n}_{C P}, \\
q_{2}:=\frac{\bar{n}_{C P}-\hat{n}_{C P}}{\left(\bar{n}_{C P}-\hat{n}_{C P}\right)+\hat{n}_{M R}}<1 ; 0<\widehat{n}_{M R}<\bar{n}_{M R}, \\
q_{3}:=0 \text { (because there are only } M R-\text { students left), }
\end{gathered}
$$

These quality definitions are consequences of the capacity constraints of the universities in the inequalities (1) and (2), as well as of the hierarchical order of student abilities. They are required to connect student quality and researcher quality in the next step.

The total number of university jobs for researchers is $\bar{R}$. This number of jobs is smaller or equal to the total number of researchers with high or moderate quality:

$$
\bar{R}_{h}+\bar{R}_{m} \geq \bar{R}
$$

Hence there is no general shortage of researchers.

To connect student quality and researcher quality — as indicated above - the quality of researchers (and, hence, of research) is defined in Eqs. (7) and (8) below. Thereby the volume of high-quality research is assumed to depend on the average quality of students as follows: 


$$
R_{h}^{1}:=R_{h}\left(q_{1}\right)>R_{h}^{2}:=R_{h}\left(q_{2}\right)>R_{h}^{3}:=R_{h}\left(q_{3}\right) \Longleftrightarrow q_{1}>q_{2}>q_{3} .
$$

Because of $q_{3}:=0$ it is assumed:

$$
R_{h}^{3}:=R_{h}\left(q_{3}\right)=R_{h}(0)=0 .
$$

The implications of these assumptions are summarized in the following lemma:

Lemma 1 Universities can be ranked according to their average quality of researchers and students. Given the types of students and the respective quality levels, three levels of universities will emerge, as indicated by Eqs. (7) and (8).

Proof The university ranking follows immediately from Eqs. (3) to (8). //

In the following, subscript $i$ denotes the universities as a group of the respective level, $i \in\{1,2,3\}$.

The next step consists of determining the decisions of profit-quality maximizing universities with regard to their tuition fees and the quality of researchers they demand. The profit of a university in Eq. (9) depends the level of fees it chooses, the research grants it acquires due to the quality of its researchers, and its endowment.

The profit function of a university in group $i$ reads then:

$$
\pi\left(R_{i}, F_{i}\right)=n_{C R} F_{h}+n_{M R} F_{h}+n_{C P} F_{l}+R_{i}\left(q_{i}\right)\left[G\left(R_{i}\right)-w\right]+A_{i} .
$$

In Eq. (9), it is assumed that the teaching of students does not have any costs over and above the payments to researchers. Put differently, it is supposed that the earnings of researchers per unit of research quality, $w$, include respective payments for teaching. The teaching load is, therefore, assumed to be the same for each researcher.

In the following, the subgame-perfect results of the game between universities, students and researchers are presented. Thereby students compete with each other for admission to the best possible university, researchers compete with other researchers to get a position at the best possible university and universities compete with each other for the best quality of students and researchers in order to maximize the profit function in Eq. (9).

Proposition 1 All CR-students, $\bar{n}_{C R}$, choose $R_{h}$ universities. The respective universities accept all these students and charge them $F_{h}$.

Proof According to their preferences, all $C R$ students will apply to $R_{h}$ universities. Given high tuition fees, $F_{h}$, moderate-gifted students will not apply at $\left(R_{h}, F_{h}\right)$ universities since the total study costs - tuition fees plus effort costs-are too high. Also $C P$ students will not apply because they cannot pay high tuition fees. Since $\bar{n}_{C R}<\bar{n}$, these universities accept all $C R$ students who will pay high tuition fees, $F_{h}$. //

When all rich and highly qualified students are allocated to universities, the crucial question is whether the remaining capacity of universities, $\bar{n}-\bar{n}_{C R}$, is used to 
accept poor, but high-quality, students or moderately gifted, but rich students. Note that universities that accept moderately-gifted students cannot be first-tier universities since this reduces their quality level according to Eq. (4). Given that universities are profit maximizers, poor but high-quality students are accepted if:

$$
\pi\left(R_{h}, \bar{n}_{C R}, \hat{n}_{C P}\right)>\pi\left(R_{h}, \bar{n}_{C R}, \hat{n}_{M R}\right)
$$

This requires:

$$
\begin{gathered}
\hat{n}_{C P} F_{l}+R_{h}\left(q_{i=1}\right)\left[G\left(R_{h}\left(q_{i=1}\right)\right)-w\right]+A_{i}> \\
\hat{n}_{M R} F_{h}+R_{h}\left(q_{i=2}\right)\left[G\left(R_{h}\left(q_{i=2}\right)\right)-w\right]+A_{i}
\end{gathered}
$$

Hence:

$$
R_{h}\left(q_{1}\right)\left[G\left(R_{h}\left(q_{1}\right)\right)-w\right]-R_{h}\left(q_{2}\right)\left[G\left(R_{h}\left(q_{2}\right)\right)-w\right]>\hat{n}_{M R} F_{h}-\hat{n}_{C P} F_{l}
$$

This relation says that a university fills the remaining seats by highly-gifted (moderately-gifted) poor (rich) students if the additional net revenues from higher grants-because of a larger number of high-quality researchers, due to a higher average quality of students, $q_{1}>q_{2}$-are higher than the additional revenues from tuition fees paid by rich students.

Proposition 2 Given the inequality in Eq. (12), universities offering $\left(R_{h} ; F_{h}, F_{l}\right)$ get $\bar{n}_{C R}, \hat{n}_{C P}$ students with $\hat{n}_{C P} \leq \bar{n}_{C P}$.

Proof Follows from Eqs. (10) to (12). //

Proposition 3 Given the inequality in Eq. (12) and $\hat{n}_{C P} \leq \bar{n}_{C P}$, some of the universities offering $\left(R_{h} ; F_{h}, F_{l}\right)$ get $\left(\bar{n}_{C P}-\widehat{n}_{C P}\right)$ poor, but high-quality students, and $\widehat{n}_{M R}<\bar{n}_{M R}$ moderately gifted students.

Proof Follows from Proposition 2 and Eq. (12).//

Note that the average quality of researchers and students at these universities is lower than at universities that get only highly-gifted students (and researchers), $q_{2}<q_{1}$. Otherwise, moderately-gifted students would not apply there. The lower research quality reduces the effort costs of moderately-gifted students such that they may accept the contract $\left(R_{h}^{2}, F_{h}\right)$.

Proposition 4 Given the inequality in Eq. (12) and $\hat{n}_{M R}<\bar{n}_{M R}$, universities offering $\left(R_{m} ; F_{h}\right)$ get no high-quality students, but all remaining $\left(\bar{n}_{M R}-\widehat{n}_{M R}\right)$ students.

Proof Follows from the capacity constraints and Propositions 2 and 3. Since all remaining moderately gifted students are rich, the respective universities on this level offer the package $\left(R_{m} ; F_{h}\right)$. // 
In effect, the above Propositions 1 to 4 imply that there are three levels of universities:

$$
\text { Level } 1:\left(R_{h}^{1} ; F_{h}, F_{l}, \bar{n}_{C R}, \hat{n}_{C P}\right) \text { with } \bar{n}_{C R}+\widehat{n}_{C P}=: \bar{n}_{1} \text {. }
$$

Level $2:\left(\bar{R}_{h}-R_{h}^{1} ; F_{h}, F_{l},\left(\bar{n}_{C P}-\widehat{n}_{C P}\right), \hat{n}_{M R}\right)$ with $\left(\bar{n}_{C P}-\hat{n}_{C P}\right)+\widehat{n}_{M R}=: \bar{n}_{2}$.

Level $3:\left(\bar{R}_{m}, F_{h},\left(\bar{n}_{M R}-\hat{n}_{M R}\right)\right)$ with $\left(\bar{n}_{M R}-\hat{n}_{M R}\right)=: \bar{n}_{3}$.

Level 1 and level 2 universities may be called research universities. Level 3 universities may be called teaching universities, because of $q_{3}=0, R_{h}^{3}=R_{h}\left(q_{3}\right)=0$.

However, at the start from the scratch of the higher education game, all universities would have the same chances to become level 1, level 2 or level 3 universities. In contrast, in the global market for higher education, the position of universities on the first level is very stable (Frank 1999; Marginson 2006; Shanghai University Ranking 2004).

Nevertheless, just from the start of the university race, universities with high foundation assets, $A_{i}$, (in the US, as well as 'Oxbridge' in the UK) had a competitive edge. ${ }^{1}$ First of all, they provided resources for research. In addition, however, they attracted students at a time when the number of persons who were able to study at a university was rather small. Moreover-although the foundation assets seem not to play a role in Eq. (12) — the respective condition for accepting high-quality, but poor students instead of moderate-quality rich students depends on the fact that a university must finance the lower tuition fees, $F_{l} \geq 0$. Also in this respect foundation assets make a difference. For these reasons, owning such assets can be the decisive edge for becoming a top university. Table 4 shows the foundation year and the endowment of the top 10 universities of the Shanghai University Ranking 2021.

To acquire a reputation as a high-quality research university takes time. During this period, research grants are not yet available. This financial gap can only be closed with financial resources from other sources. With imperfect capital markets, foundation assets, $A_{i}$, provide these monetary resources. In such a situation, a small financial advantage might be sufficient to become a level 1 university. One could also argue that further assets given to the university in the form of donations by alumni can also be a positive function of the reputation reached so far over time.

Having acquired the competitive edge in the market for higher education, university rankings over the years demonstrate that the leading institutions are very stable. To compete with them, the model in this section demonstrates the following possibilities:

\footnotetext{
1 Of course, also different stories may be told about the origin of the competitive edge. In effect, all of them are variants of the so-called "Matthew effect" (Merton, 1968) or "preferential attachment" (see, for instance, Hofstad, 2016; see also Yule, 1925, and Simon, 1955). All stories begin with a small advantage that sets into motion a dynamic process in which this advantage becomes increasingly larger over time. However, it is not intended to model this dynamic process in this article.
} 
Table 4 Foundation year and endowment of the top 10 universities of the Shanghai University Ranking

\begin{tabular}{llll}
\hline University $^{1}$ & $\begin{array}{l}\text { Shanghai Ranking } \\
2021^{2}\end{array}$ & Foundation year & $\begin{array}{l}\text { Endowment } \\
\text { in billion } \\
\text { USD }\end{array}$ \\
\hline Harvard University & 1 & 1636 & 37.6 \\
Stanford University & 2 & 1891 & 27.7 \\
University of Cambridge & 3 & 1209 & n. a \\
Massachusetts Institute of Technology & 4 & 1861 & 10.9 \\
University of California, Berkeley & 5 & 1868 & 4.05 \\
Princeton University & 6 & 1746 & 26.1 \\
University of Oxford & 7 & ca. 1096 & $8.2^{3}$ \\
Columbia University & 8 & 1754 & 11.3 \\
California Institute of Technology & 9 & 1891 & 2.9 \\
University of Chicago & 10 & 1890 & 8.2 \\
\hline
\end{tabular}

${ }^{1}$ All information about the universities are taken from Wikipedia (English) on 30 September 2021

${ }^{2}$ Shanghai University Ranking (2021)

${ }^{3} 6.1$ bn $£$ (exchange rate: $1 £=1.35$ USD (30 September 2021)

(1) Provide huge investments in a very few universities, i.e., $A_{i}$.

(2) Attract top researchers, $R_{h}$, globally by offering excellent students ( $C R$ and $C P$ students) and the opportunity to acquire grants, $G(R)$.

(3) Attract the best students worldwide (see the previous point) by offering them respective contracts, $\left(R_{h} ; F_{h}, F_{l}\right)$.

As can be seen by (3), universities may have a competitive disadvantage in this respect if they are legally not allowed to demand tuition fees from students, as for instance in Germany.

\subsection{State universities, state-sponsored student grants and internationalization}

The question is whether state-sponsored student grants, in combination with state universities, can make a difference in this respect (Aghion et al. 2009). The idea is as follows. Imagine a university that selects prospective students according their academic records in high school. For those who cannot afford university education, student grants are paid by the state that have to be repaid to a large extent when students are having a job afterwards.

Given that universities are free to compete for students (and researchers who will be also teachers) and that they can select their own students as they want, it would be possible to establish nationally a three-tier league system of universities as in the preceding model. Small advantages, either by chance or by other situational factors, will be sufficient to establish a three-tier league structure in which the first tier is very stable. 
However, changes may have a great influence on the structure of this league system. Imagine that high school grades do no longer signal student quality and it is not allowed for universities to test themselves ex ante the prospective students' quality. This would destroy the selection of students by universities. The average student quality would become more or less equal among universities. As a consequence, the average quality of researchers would also be equalized. However, with competition from abroad research universities, highly qualified researchers, as well as students, may leave the respective country.

To make such a university system more competitive with respect to high-quality research universities abroad, additional financial support is given to a few universities that provide the most promising research proposals (as, for instance, in the so-called Excellence Initiative in Germany; see Menter et al. 2018). Although this might provide incentives to engage in high-quality research, the allocation of students to universities may not change due to a lack of methods for student selection.

Leaving the student allocation issue aside, the internal three-tier league system may be restored in this way. Nevertheless, international competitiveness concerning high-quality researchers can only be achieved if the additional financial resources are sufficiently high to attract a large number of foreign researchers or to prevent their own young highly gifted researchers from leaving the country.

\section{Empirical evidence on the stability of universities' rankings}

We have shown in our model that having reached a competitive edge in the market for higher education, university rankings over the years will demonstrate that the leading institutions are in stable ranking positions. To compete with them, huge investments would be necessary in both highly-qualified students and excellent researchers.

When looking for a frame of reference, changes in the ranking of the globally most highly capitalized firms come to mind; in 2019 these were firms like Apple, Facebook and Microsoft. To get an idea we looked at the top ten of these firms in 2004 and in 2019, only finding one firm by the name of Microsoft present in both rankings.

Regardless of the fact that using firms as a benchmark is tempting, the way of doing business has changed dramatically over the last decades and centuries, giving innovative entrepreneurs good business opportunities. The way of "doing education" has not changed much over the last centuries. Therefore it does not come as a surprise that many more businesses-with innovative ideas-have been founded very successfully in the recent past, compared to newly-founded or newly aspiring universities.

When we look at university rankings we see the high stability of ranking positions of universities over time. The rank correlations for the top 20 and top 50 universities in the Shanghai Ranking are shown in Tables 5 and 6. We see the high stability of both ranking intervals, increasing with the rank positions. As is expected, the rank correlations (Spearman's rank-order correlation and Kendall's Tau) of the 
Table 5 Rank correlations of top 20 universities, Spearman rank-order correlation (in parentheses Kendall's Tau)

\begin{tabular}{llllll}
\hline & Rank 2004 & Rank 2009 & Rank 2014 & Rank 2019 & Rank 2021 \\
\hline Rank 2004 & $\begin{array}{l}1.0000 \\
(1.0000)\end{array}$ & & & \\
& 0.9779 & 1.0000 & & & \\
Rank 2009 & $(0.9118)$ & $(1.0000)$ & & & \\
& 0.9638 & 0.9798 & 1.0000 & & \\
Rank 2014 & $(0.8603)$ & $(0.9044)$ & $(0.9926)$ & & \\
& 0.9491 & 0.9491 & 0.9718 & 1.0000 & $(0.9926)$ \\
Rank 2019 & $(0.8456)$ & $(0.8162)$ & $(0.8824)$ & 0.7627 & 1.0000 \\
& 0.7377 & 0.7500 & 0.7615 & $(0.7426)$ & $(1.0000)$ \\
\hline
\end{tabular}

All values are statistically significant at the 1\% level.- Source: Shanghai University Rankings (2004, 2009, 2014, 2019, 2021); own calculations

Table 6 Rank correlations of top 50 universities, Spearman rank-order correlation (in parentheses Kendall's Tau)

\begin{tabular}{llllll}
\hline & Rank 2004 & Rank 2009 & Rank 2014 & Rank 2019 & Rank 2021 \\
\hline Rank 2004 & $\begin{array}{l}1.0000 \\
(0.9919)\end{array}$ & & & & \\
& 0.9858 & 1.0000 & & & \\
Rank 2009 & $(0.9121)$ & $(0.9929)$ & & & \\
& 0.9718 & 0.9872 & 1.0000 & & \\
Rank 2014 & $(0.8667)$ & $(0.9182)$ & $(0.9899)$ & & \\
& 0.6236 & 0.6460 & 0.6778 & 1.0000 & $(0.9909)$ \\
Rank 2019 & $(0.5818)$ & $(0.6111)$ & $(0.6566)$ & 0.8178 & 1.0000 \\
& 0.4723 & 0.5079 & 0.5479 & $(0.7606)$ & $(0.9949)$ \\
\hline
\end{tabular}

All values are statistically significant at the 1\% level.-Source: Shanghai University Rankings (2004, 2009, 2014, 2019, 2021); own calculations

top 20 show that there are almost no changes in the rankings over the time period 2004-2019. Only the 2021 ranking shows lower rank correlations.

Even the rankings of the top 50 universities are remarkably stable, as can be seen in Table 6.

The problem of aspiring universities may not (only) be financial means. To attract famous researchers and brilliant students, universities have to offer a worldwide reputation, which is difficult to be built up from scratch.

For a more precise demonstration of the stability of the top ranks of universities, Fig. 1 shows the distribution of the "average ranking success" of the top 100 universities in the five available Shanghai University Rankings (2004, 2009, 2014, 2019 and 2021). Average ranking success is measured as follows:

$$
\text { Average success } s_{i}=\frac{5-m_{i}}{\sum_{t=1}^{5} r_{i, t}} .
$$


Table 7 Test of the Pareto-distribution for the Top 100 universities

\begin{tabular}{lllllr}
\hline Top univer-sities & \multicolumn{2}{l}{ Parameters pareto-distribution } & & \multicolumn{2}{l}{ Probability pareto-distribution } \\
\cline { 2 - 3 } \cline { 5 - 6 } & $a$ & & & Cramér-von Mises & Watson \\
\hline Top 20 & $1.1822^{* * *}$ & $0.0515^{* * *}$ & & 0.9905 & 0.9842 \\
Top 50 & $1.1113^{* * *}$ & $0.0212^{* * *}$ & & 0.9885 & 0.9809 \\
Top 100 & $1.2447 * * *$ & $0.0126 * * *$ & & 0.0509 & 0.0636 \\
\hline
\end{tabular}

${ }^{* * * *}$ Statistically significant at the $0.01 \%$ level.-Source: Shanghai rankings $(2004,2009$. 2014, 2019, 2021); own calculations

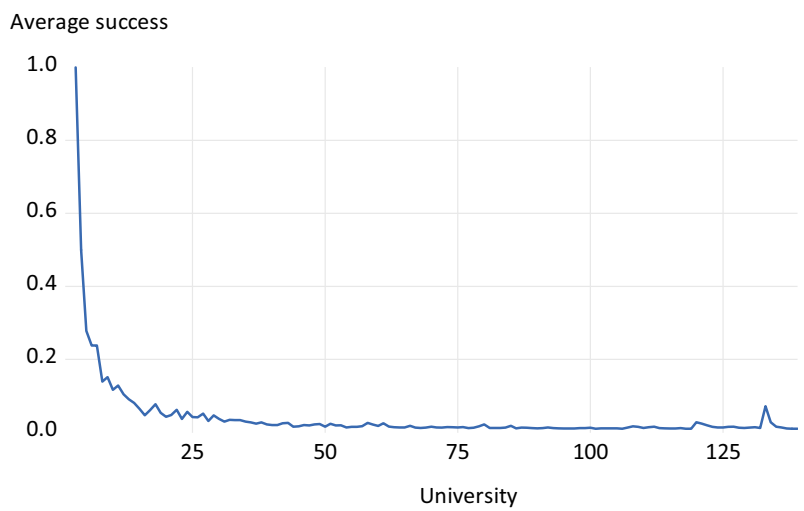

Fig. 1 Distribution of "average ranking success" in the top 100. Source: Shanghai University Ranking (2004, 2009, 2014, 2019, 2021); own calculations

In Eq. (16), the average ranking success of a university $i$ is given by its inverse average ranking position, with $r_{i, t}$ as the rank of university $i$ in the ranking $t=1$ (2004) to 5 (2021). Since not all universities reached a rank in the top 100 in all five rankings, the years missed are accounted for by $m_{i} \in\{0,1,2,3,4\}$. In total, 137 universities have been ranked so far in the top 100 of the Shanghai ranking.

As Fig. 1 demonstrates, the distribution of average ranking success is highly skewed. Only a few universities are constantly very successful in this ranking. The empirical distribution tests provide evidence for a Pareto distribution of the top 100 rankings, as the data in Table 7 underline. Note that for these empirical distribution tests the following Pareto distribution was estimated:

$$
f(x \mid a, k)=\frac{a \cdot k^{a}}{x^{a+1}}, \mathrm{x}=\text { Average success, a, } \mathrm{k} \text { : parameters (to be estimated). }
$$

According to the results of the empirical distribution tests, a Pareto distribution up the top 50 ranked universities cannot be excluded. This is a further indication for the fixed top positions in the Shanghai (and other) university rankings. 


\section{Successful entry into the super league?}

Given these fixed top positions in the global university rankings, is there still leeway for getting into the super league of universities? Are there still any effects of projects like the German Excellence Initiative, launched in 2004? MacLeod and Urquiola (2021) have shown that the success story of US Universities is not the consequence of design, but rather of competition helping to create a confluence of incentive mechanisms that lead to the actual performance.

For the recruitment of students, Fischer and Kampkötter (2017) found for Germany that designated "universities of excellence" attracted the ones with better high-school grades. This was statistically significant for three years following the award of the excellence status, indicating that the award had a positive effect on student selection for successful universities. Interestingly, they could not find a positive effect of the award on these enrollments in the longer run. However, it should be noted that Germany lacks a test that is comparable to the Scholastic Assessment Test, SAT. The grades used by Fischer and Kampkötter (2017) are vulnerable to grade inflation and, unfortunately, do not contain much variance. Moreover, as the output quantity of the "universities of excellence" increased, research quality suffered (Civera et al. 2020).

In Proposition 1 we stated that all highly-gifted rich students, $\bar{n}_{C R}$, choose highquality research universities (elite schools), $R_{h}$. The respective universities are assumed to accept all these students and charge them high fees, $F_{h}$. These universities only fill the remaining seats with highly-gifted (moderately-gifted) poor (rich) students if the additional net revenues from higher grants-because of a larger number of high-quality researchers, due to a higher average quality of studentsare higher than the additional revenues from tuition fees paid by rich students. Furthermore, second-tier (nonelite) schools accept the remaining poor, but highlygifted students and some moderately-gifted rich students. Hence, the average family income of students in elite schools will be higher than the respective income of students in non-elite schools. ${ }^{2}$ We see this proposition mirrored by the university ranking reality. Cook and Frank (1993) report studies that the average family income of students attending elite colleges and universities is far higher than the average family income of students at nonelite schools (in the terminology applied here, second tier schools). Family income is also an important predictor of attendants of an elite school, even after controlling for standardized test scores, parents' education, and other personal characteristics (Hearn, 1990; Spies 1990). In that respect, also the best rich foreign students will aspire to attend an elite US university.

As shown above in Eq. (7), the volume of high-quality research in our model depends on the average quality of students. As a consequence, the brightest researchers also have a tendency to follow both their best peers and the group of the globally brightest students. Keep in mind that for the Shanghai University Ranking the quality of the alumni enters with a weight of $10 \%$. This quality, which links research and

\footnotetext{
${ }^{2}$ However, including third-tier schools would change this, because they are attended by moderatelygifted rich students only.
} 
student quality, is measured by the number of the alumni winning Nobel prizes and Fields medals.

It remains an open question which efforts it takes to upgrade e.g. German or Chinese universities to a highly recognized global reputation with a university ranking among the top 30. To overcome its disadvantages against top league institutions, an aspiring university in the beginning only has two variables: the wage of researchers, $w$, and some extra endowment, $A_{i}$. It is an open question if a wage exists that could motivate star researchers to migrate to a lower level university. Also, it is open to debate whether new players in the market can mobilize enough extra endowments, given all the active alumni that donate to the top league universities.

We start with the incentives provided by wages for researchers already working for specific national universities, which have been changed dramatically in China. To improve the position of Chinese universities researchers have been awarded cash prizes, housing benefits or other perks on the basis of high-profile publications (Qiu 2010). In 2010 the pressure to publish was already high but still growing. A study from Wuhan University estimated a large market for ghostwriting papers on nonexistent research, that in 2009 was five times the amount it was in 2007. It also was revealed to the journal Nature that one in three researchers surveyed at major universities and research institutions admitted to committing scientific fraud (Qiu 2010).

These very strong incentives to improve the performance of researchers have obviously been badly designed. The incentives have encouraged questionable research practices, which through lots of retractions of Chinese publications in international high profile journals have undermined the objective of improving the standing of Chinese universities.

Therefore at the end of 2020 a new policy was designed to cope with these perverse incentives by banning cash rewards for publishing (Mallapaty 2020). As part of the new policy, researcher assessments could be also partly be influenced by bureaucrats and will now need to use indicators of the quality of research, such as how innovative the work is, and whether it represents a significant scientific advance or contributes to solving important societal problems. Because this new policy also has a focus on publishing in Chinese journals, it could have the consequence of international researchers becoming less interested to collaborate with Chinese researchers (Mallapaty 2020).

A good example for a very large extra endowment, at least by German standards, is the Excellence Initiative. While in 2004 one German university was among the top 50 in the Shanghai ranking, in 2009 the best was ranked only 55. In 2014, two universities were among the top 50 while in 2019 there was only one and 2021 none. As explained above, to attract famous researchers and brilliant students the investments must be huge. The official Report of the Excellence Initiative, the Imboden Report (2016, p.15), has put the German investments into a global perspective: "If the entire annual expenditure of the Excellence Initiative were available to RWTH [Aachen, the authors], its budget would be roughly the same as that of the University of Michigan, which also has similar student numbers, or that of ETH Zurich, which has fewer than half of the students." The ETH Zurich, by the way, was among the top 20 in 2014, 2019 and 2021. Therefore, it does not come as a surprise that only three new Chinese universities made it into 
the top 50 in 2021 from ranks above the top 100: Peking University (\# 53 in 2019 and \#49 in 2021), Tsinghua University (\#43 in 2019, \#29 in 2021) and Zhejiang University (\#70 in 2019, \#58 in 2021). These universities are said to have made investments comparable with US top universities.

The advantages of top tier universities have cumulated over time and are therefore very high. The initiatives sketched above that were designed in China and Germany to overcome the disadvantages of their universities against top league institutions using wages of researchers and some extra endowment, seem to have lead to mixed results at best. Especially, the strong incentives before seem to have had a rather detrimental effect on performance in China. These strong short term incentives were not able to stand up to a scientific culture that had grown over centuries.

It has to be noted that these iniatives are not only up against the cumulated advantages of the past, but as MacLeod and Urquiola (2021) find, against a permanent sorting process at US top tier universities, allowing them to attract the most talented students along with high tuition payments and donations. It is not only short-term changes in wages or some temporary extra endowment, but a whole system of complementary and self-reinforcing dynamics concentrating research-talented professors and strong students - increasingly from all over the world — at a few top tier schools.

Apart the Chinese and German attempts to get into the super league of universities, France started in 2010 to create such universities. The first one was PSL University (Université de recherche Paris Sciences et Lettres) that encompasses five formerly independent grandes écoles, among others, the renowned Collège de France (Wikipedia 2021). It reached rank 36 in the Shanghai rankig of 2021. Moreover, a second university for science and technology was established in a similar manner, Paris-Saclay University. The Shanghai University Ranking published in 2021 shows that the intention to bring a university into the top 10 universities almost succeeded, as Paris-Saclay University reached rank 14. In effect, 19 former autonomous institutions merged, some of them established and well-know universities, as for instance, ten grandes écoles and seven national research institutions (Thoenig 2015). A new campus was constructed that is connected with an technology cluster and grants of about $€ 2.5$ billion had been collected, according to Thoenig (2015).

As indicated in the model of Sect. 3 above, the success of such newly created universities depends on foundation assets - in the French case, provided by the state - , but also on the ability to attract high-ability students and researchers. As it seems, the Chinese and French ways to create very successful universities were more successful than the German way, at least up to now. In contrast to Germany, France concentrated on combining already existing universities and on giving them the necessary financial means. But alone when checking the corporate identity of Paris Sanclay University you still find faculty websites in french language. It remains to be seen whether the foundation of this new university is more than an accounting measure of just summing up the scores of unrelated existing institutions to boost a ranking position. This would resemble the failed financial holding strategies of the 1960s in business, with its top-down decision approach; the US approach is bottomup, because every top university itself can make strategic decisions. 


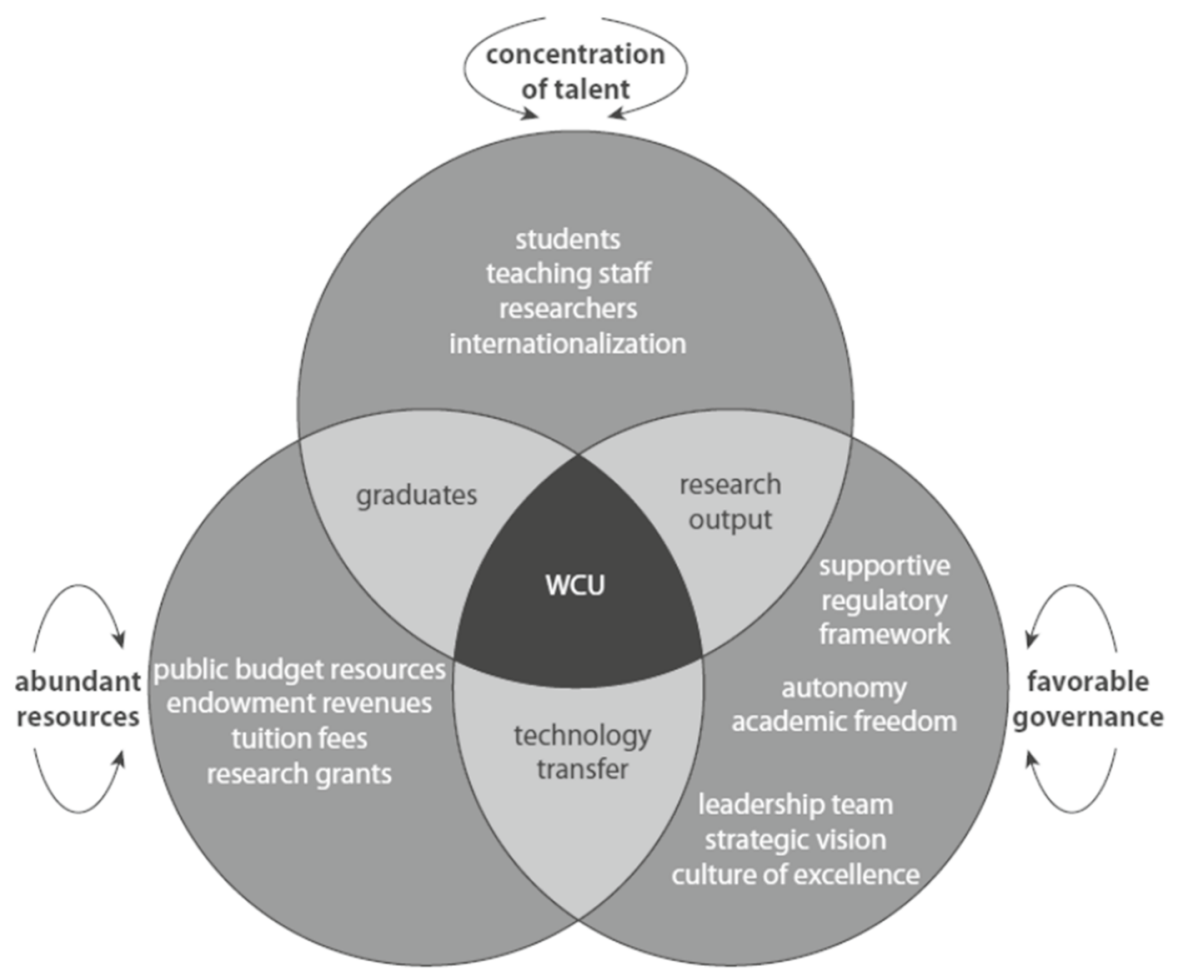

Fig. 2 Characteristics of a super league university: Alignment of key factors

So far, we have analyzed the university hierarchy system in a restricted manner. When we take a broader look at the characteristics of a super league university (see Fig. 2), the differences with the business sector become immediately obvious. While firms need successful innovative business models, i.e. strategies, in market environments favorable to their survival, the success of universities stems from a much simpler formula. The success of universities essentially consists of abundant money resources, both good researchers and students, as well as favorable governance and a convenient regulatory environment. The latter are not included directly into the model in Sect. 3 above, but only indirectly. Nevertheless, in recent times university governance became a topic for concern (Blackman et al. 2007; OECD 2007; Blackman and Kennedy 2009) and for strategic considerations (Bratianu and Pinzaru 2015). Meanwhile, it was recognized that especially in Europe "[f]ragmented goals and poorly defined objectives", as well as "dispersed capacity and capability" (Estermann and Kupriyanova 2018, p. 12) are obstacles in the adaptation of universities to a changing environment and better ranking positions.

Moreover, two important assumptions reflect the regulatory environment of successful institutions: (1) Universities are free to test and to admit the students they want. (2) Due to their profit and quality orientation, they can acquire their financial means by themselves without being dependent on politically decided budgets. These factors have to be cherished for a long time. The most successful universities 
(among the top 20) are old, many of them founded long before 1800, and they have also been cherished accordingly. The advantages that lead to ranking-stability have cumulated over time and are therefore very high. Accordingly, no private investor but only states (or existing non-profit universities) are trying to invest in the upgrade of universities to catch up. As we have seen, the financial, moral and societal costs of the above sketched initiatives are really high, but their benefits given the cumulated advantages of top tier universities in the US are at best uncertain. Let us assume that states like China or Germany would be successful in strongly improving the ranking position of some of their universities. It seems unclear how sustainable the benefits of such successes would be, given the top tier universities in the US are embedded in a complex and completely different system of complementary and self-reinforcing dynamics (MacLeod and Urquiola 2021).

Private investors active on the for-profit side of higher education offer a no-frills education oriented towards specific technical skills with high labor market returns. They are earning money without investing (much) in reputation and research. While for-profit investors in higher education pursue valuation by students in dollar terms, their non-profit competitors pursue reputation with the external world.

It becomes clear that one only can make money in this sector when you leave normal competition with the established universities. The classical university business model - for all the reasons explained so far-is perhaps doomed to die, and it, therefore, can only be afforded by states and affluent non-profit institutions. But it is and will be very profitable for competitors to cut out attractive niches from this business segment. This can e.g. be business school offerings that compete with non-profit business schools. As far as reputation and research become less important for students, alternative offerings tailormade to market needs may become more popular. This is especially important in all dynamic business sectors where e.g. digitalization plays a large role. Here courses with direct business impact, but without certificates are in high demand by professionals who are already successful in their trades. The above reasoning on niche competitors of established universities will apply to companies like Singularity University. Given that these niches make the options for certain courses very attractive, we conjecture that we will see further erosion of low to medium level state universities overtime because they can neither compete with reputation oriented high-level universities nor with the highly market-oriented niche offerings from for-profit providers. In that respect, they are threatened to end up stuck in the middle between these two market segments.

\section{Conclusion}

The "war for talents" is on in academia. The ranking of universities signals prospective students their ability to provide them with a status that may be used to get better jobs and higher reputation. At the same time, universities are screening students with this status in order to attract the most gifted of them. Moreover, having excellent students at a university is a device to get highly-qualified researchers who can successfully apply for government-sponsored research contracts. 
In this matching game, universities with large own funds have an advantage because they can attract poor, but highly-gifted students with student grants or low (no) tuition fees. In a world with highly-gifted and moderately-gifted students, the allocation of highly gifted students is decisive for becoming a super league university. In effect, a three-tier league system of universities may emerge endogenously in such a context. In this league system, tier one and tier two universities might be called research universities, whereas tier-three universities would be teaching universities.

The Shanghai University Ranking from 2004 to 2021 provides empirical evidence for the existence of such a league system. In particular, the global super league of universities encompasses more than half of the top 100 universities in the Shanghai ranking. The rank distribution of these universities seems to be very stable. This means that it is hardly possible to get into this super league. To put it differently: to get into this super league of universities, huge investments are required.

Recent attempts in Germany and China yielded mixed results in this respect. Germany could not get a university into the top 20 or top 30 ranks in all of the Shanghai University Rankings so far. China surpassed the US with published scientific and technical papers, and it managed to get one university into the top 30. Obviously, it takes a lot of time to make it into the super league, even with huge investments. Nevertheless, as demonstrated by France, it is also possible to get to top positions in the rankings by combining forces, i.e., to concentrate research power-whether real or only by labelling - in a very few top institutions. But even then success will be less than certain. And when societal and moral costs accompanying the very strong incentives as the ones used in China are taken into account, even successes in the upgrade of universities may have overall negative external effects. For all the reasons explained so far, the classical university business model is perhaps in the mature phase of its life cycle. But this state of affairs gives states the freedom to take a fresh look on new successful business models of higher education. For Germany e.g., promoting universities anchored in the region which are the incubators and "hubs" of different forms of knowledge (Frey and Osterloh 2020), could be more profitable than competing for top ranking positions.

Funding Open Access funding enabled and organized by Projekt DEAL.

Open Access This article is licensed under a Creative Commons Attribution 4.0 International License, which permits use, sharing, adaptation, distribution and reproduction in any medium or format, as long as you give appropriate credit to the original author(s) and the source, provide a link to the Creative Commons licence, and indicate if changes were made. The images or other third party material in this article are included in the article's Creative Commons licence, unless indicated otherwise in a credit line to the material. If material is not included in the article's Creative Commons licence and your intended use is not permitted by statutory regulation or exceeds the permitted use, you will need to obtain permission directly from the copyright holder. To view a copy of this licence, visit http://creativecommons.org/licen ses/by/4.0/. 


\section{References}

Aghion P, Dewatripont M, Hoxby C, Mas-Colell A, Sapir A (2009) The governance and performance of research universities: evidence from europe and the U.S.. Working paper 14851, National Bureau of Economic Research, Cambridge

Altbach PG, Salmi J (eds) (2011) The road to academic excellence. The World Bank, Washington D.C.

Basu K (1989) A theory of association: social status, prices and markets. Oxf Econ Pap 41(4):653-671

Becker WE (1975) The university professor as a utility maximizer and producer of learning, research, and income. J Hum Resources 10(1):107-115

Becker WE (1979) Professorial behavior given a stochastic reward structure. Am Econ Rev 69(5):1010-1017

Becker WE, Kennedy PE (2005) Does teaching enhance research in economics? Am Econ Rev 95(2):172-176

Bezès P (2021) Teaching is the essential complement to research. URL: https://www.sciencespo.fr/en/ news/news/\%E2\%80\%9Cteaching-essential-complement-research\%E2\%80\%9D/2626. Accessed 7 July 2021

Blackman D, Kennedy M (2009) Knowledge management and effective university governance. J Knowl Manag 13(6):547-563

Blackman D, Kennedy M, Swansson J, Richardson A (2007) University governance in uncertain times. Australasian Association for Institutional Research, Sydney

Bratianu C, Pinzaru F (2015) University governance as a strategic driving force. In: Proceedings of 11th European conference on management leadership and governance, Military Academy, Lisbon, Portugal, 12-13 November 2015, 28-35.

Chellaraj G, Maskus KE, Mattoo A (2008) The contribution of international graduate students to US innovation. Rev Int Econ 16(3):444-462

Civera A, Lehmann EE, Paleari S, Stockinger SAE (2020) Higher education policy: why hope for quality when rewarding quantity? Res Policy 49:104083

Cohn E, Cooper S (2004) Multiproduct cost functions for universities: economies of scale and scope. In: Johnes G, Johnes J (eds) International handbook on the economics of education. Edward Elgar, Cheltenham, pp 579-612

Cook PJ, Frank RH (1993) The growing concentration of top students at elite schools. In: Clotfelder CT, Rothschild M (eds) Studies of supply and demand in higher education. University of Chicago Press, pp 121-144

De Fraja G, Iossa E (2002) Competition among universities and the emergence of the élite institution. Bull Econ Res 54(3):275-293

Demange G, Fenge R, Uebelmesser S (2020) Competition in the quality of higher education: the impact of student mobility. Int Tax Public Financ 27:1224-1263

Dillon WE, Smith JA (2017) Determinants of the match between student ability and college quality. J Law Econ 35(1):45-66

Dillon WE, Smith JA (2019) The consequences of academic match between students and colleges. J Hum Resources. https://doi.org/10.3368/jhr.55.3.0818-9702R1

Dynarski S, Libassi CJ, Michelmore K, Owen S (2018) Closing the gap: The effect of a targeted, tuitionfree promise on college choices of high-achieving low-income students. NBER Working Paper No. 25349.

Estermann T, Kupriyanova V (2018) Efficiency, leadership and governance: closing the gap between strategy and execution. European University Association, Bussels

Fischer M, Kampkötter P (2017) Effects of German universities' Excellence Initiative on ability sorting of students and perceptions of educational quality. J Inst Theor Econ 173:662-687

Frey B, Osterloh M (2020) Deutschland braucht kein Harvard. FAZ 07(12):2020

Grazzini L, Luporini A, Petretto A (2011) Competition between state universities. CESifo working paper no. 3373. Center for Economic Studies and Ifo Institute, University of Florence, Munich

Grewal R, Dearden JA, Llilien GL (2008) The university rankings game. Am Stat 62:232-237

Hazelkorn E (2011) Globalization and the reputation race. In: Rankings and the reshaping of higher education. Palgrave Macmillan, London, pp 1-25. https://doi.org/10.1057/9780230306394_2

Hazelkorn E (2015) Rankings and the Reshaping of Higher Education. Palgrave Macmillan, New York 
Hofstad R (2016) Preferential attachment models. In: Random graphs and complex networks (Cambridge Series in Statistical and Probabilistic Mathematics, pp. 256-300). Cambridge: Cambridge University Press.

Hoxby C (2009) The changing selectivity of American colleges. J Econ Persp 23:95-118

Hoxby C, Avery C (2013) The missing, one-offs': the hidden supply of high-achieving, low-income students. Brookings Papers Econ Activity Spring 2013:1-50

Hoxby CM, Turner S (2015) What high-achieving low-income students know about college. Am Econ Rev 105(5):514-517

Kehm BM, Stensacker B (eds) (2009) University rankings, diversity, and the new landscape of higher education. Sense Publishers, Glasgow

Laura T (2021) Tuition fees around the world, Internet URL: https://www.topuniversities.com/studentinfo/student-finance/tuition-fees-worlds-top-universities. Accessed 28 June 2021

LERU (2017), Excellent Education in Research-Rich Universities, LERU.org.

MacLeod WB, Urquiola M (2015) Reputation and school competition. Am Econ Rev 105(11):3471-3488

MacLeod WB, Urquiola M (2021) Why does the United States have the best research universities? Incentives, resources, and virtuous circles. J Econ Persp 35:185-206

Mallapaty S (2020) China bans cash rewards for publishing. Nature 579(5):18

Marginson S (2006) Dynamics of national and global competition in higher education. High Educ 52:1-39

Mause K (2009) Too much competition in higher education? Some conceptual remarks on the excessivesignaling hypothesis. Am J Econ Sociol 68(5):1107-1134

Menter M, Lehmann EE, Klarl T (2018) In search of excellence: a case study of the first excellence initiative of Germany. J Bus Econ 88:1105-1132

Merton RK (1968) The Matthew effect in science. Science 159(3810):56-63

Moed HF (2017) A critical comparative analysis of five world university rankings. Scientometrics 110:967-990

OECD (2007) On the edge: securing a sustainable future for higher education. OECD, Lausanne

Oliveira T (2006) Tuition fees and admission standards: How do public and private universities really compete for students?, Working Paper No. 06/6, Department of Economics, University of Leicester, Leicester.

Poole DC (2018) Teaching and research excellence: complimentary sides of the same coin, Internet URL: https://community.acue.org/blog/teaching-and-research-excellence-complimentary-sides-of-thesame-coin/. Accessed 7 July 2021

Qamar uz Zaman M (2004) Review of the academic evidence on the relationship between teaching and research in higher education. Department of Education and Skills, Nottingham

Qiu J (2010) Publish or perish in China. Nature News, 463, 14 jan. 2010, 143

Roberts T, Thompson L (2007) University league tables and the impact on student recruitment. Reputation Management for Universities, Working Paper Series No. 2, The Knowledge Partnership, Leeds.

Romero L, Del Rey E (2004) Competition between public and private universities: Quality, prices and exams. Working paper 04-64, Department of Economics, Universidad Carlos III de Madrid, Getafe.

Rothschild M, White LT (1995) The analytics of the pricing of higher education and other services in which the customers are inputs. J Polit Econ 103(3):573-586

Shanghai University Ranking (2004, 2009, 2014, 2019, 2021) Academic ranking of World Universities. Shanghai Jiao Tong University, Internet URL: http://www.shanghairanking.com/. Accessed 25 June 2021

Simon HA (1955) On a class of skew distribution functions. Biometrika 42(3-4):425-440

Thoenig J-C (2015) Why France is building a mega-university at Paris-Saclay to rival Silicon Valley. URL:https://theconversation.com/why-france-is-building-a-mega-university-at-paris-saclay-torival-silicon-valley-41786. Accessed 27 June 2021

US Department of Education (2021) National center for education statistics. Digest of Education Statistics, 2019 (NCES 2021-009), Table 330:10

Wikipedia (2021) Paris Sciences et Lettres University. https://en.wikipedia.org/wiki/Paris_Sciences_et_ Lettres_University. Accessed 27 June 2021

Williams N (1997) U.K. universities-jostling for rank. Science 275(5296):18-19

Winston GC, Zimmerman DJ (2004) Peer effects in higher education. In: Hoxby CM (ed) College choices: the economics of where to go, when to go, and how to pay for it. University of Chicago Press 
World Bank (2017) Scientific and technical journal articles. https://data.worldbank.org/indicator/ip.jrn. artc.sc. Accessed 8 Apr 2020

World Bank (2019) GDP (current US \$). World Development Indicators, Internet URL: https://data.world bank.org/indicator/NY.GDP.MKTP.CD. Accessed 30 June 2021

Yule GU (1925) A mathematical theory of evolution, based on the conclusions of Dr. J. C. Willis. Philos Trans R Soc B 213(404-410):21-87

Zimmerman DJ (2003) Peer effects in academic outcomes: evidence from a natural experiment. Rev Econ Stat 85(1):9-23

Publisher's Note Springer Nature remains neutral with regard to jurisdictional claims in published maps and institutional affiliations. 